\title{
Molecular characterizations of the entomopathogenic nematodes, Heterorhabditis bacteriophora and Oscheius myriophilus from Iraq
}

\author{
Jawad B. Al-Zaidawi ${ }^{1}$, Javad Karimi ${ }^{2^{*}}$ (D) and Esmat Mahdikhani Moghadam²
}

\begin{abstract}
A survey was conducted in three main regions of Iraq to isolate and identify entomopathogenic and insect parasitic nematodes. Soil samples were collected from 15 sites across 3 provinces from grassland, date palm, and citrus fields, and tested for the presence of nematodes. Out of 100 samples collected, 2 isolates of nematodes were recognized. The collected specimens were characterized first morphologically and then by molecular studies to characterize and identify the isolates based on ITS and 185 rDNA genes. Both isolates were recovered from soil samples of citrus and palm orchards located in 3 regions in the city of Baghdad. The isolates were identified by analyzing sequenced results and then by DNA sequences that were blasted against the NCBI database in GenBank. The 2 isolates were separated into 2 genera, assigned as IRQ.1 and were identified as Heterorhabditis and IRQ.2, that was identified as Oscheius. Molecular analysis and phylogenetic relationship of both genera were analyzed, using the DNA sequences of 2 loci. The Heterorhabditis species was assigned as Heterorhabditis bacteriophora, while the Oscheius species was identified as Oscheius myriophilus. These species were the first to be reported in Iraq.
\end{abstract}

Keywords: Survey, Entomopathogenic nematodes, Heterorhabditis, Oscheius, Molecular identification, Iraq

\section{Background}

Entomopathogenic nematodes (EPNs) from families Steinernimatidae and Heterorhabdidae are lethal parasites of a wide range of insect pests worldwide. Species of EPNs have effectively been used as biological control agents to control and manage significant pests of commercial crops, especially soil-dwelling insect pests and plant-boring pests in some countries such as the USA and European countries (Hazir et al. 2004). The EPNs can kill target insects within $48 \mathrm{~h}$ and are considered as an obligate insect's parasite (Kaya and Gaugler 1993). Photorhabdus (Boemare 2002) and Xenorhabdus (Thomas and Poinar 1983) are symbiotically associated bacteria with Heterorhabditis and Steinernema, respectively. These nematodes could be used effectively to control insect pests, especially when these originated from

\footnotetext{
*Correspondence: jkb@um.ac.ir; javadkarimi10@gmail.com 2Department of Plant Protection, Ferdowsi University of Mashhad, Mashhad, Iran

Full list of author information is available at the end of the article
}

the same area of target pests as indigenous agents (Stock et al. 1999). These biocontrol programs have received huge attention in many countries globally, as these agents have special traits such as searching for the insect pests in cryptic habitats, massive reproductive ability, easy mass-production laboratory potential, safety to humans, and other vertebrates as well non-target insects (Akhurst and Smith 2002). More than 100 species of Steinernema and 16 species of Heterorhabditis have been recorded (Shapiro-Ilan et al. 2017). Some of these nematodes are produced commercially in some countries and have been used successfully as biological control agents. These include Heterorhabditis bacteriophora, $H$. indica, $H$. marelata, $H$. megidis, $H$. zealandica, Steinernema carpocapsae, S. feltiae, S. glaseri, S. kushidai, S. kraussei, S. longicaudum, S. riobrave, and S.scapterisci (Kaya et al. 2006; and Lacey et al. 2015).

Recently, the genus Oscheius was discovered, as a new member of EPNs (Torres-Barragan et al. 2011). Some Oscheius spp. have a symbiotic relationship with 
symbiotic bacteria. Oscheius species are parasitic and lethal to some insect pests and some are also effectually associated with Serratia bacteria (Lephoto et al. 2015; and Torrini et al. 2015). According to the criteria of EPNs, their entomopathogenicity has not yet been examined (Dillman et al. 2012). Darsouei et al. (2014) reported two new species, Oscheuis rugaoensis and Pristionchus maupasi, isolated from the white grub larvae Polyphylla adspersa. These were the first reported of the Oscheius genus from Iran. Additionally, the Oscheius species were isolated from vermicompost in the USA. Preliminary experiments showed that these nematodes had the potential to infect and kill the two insect species, Pieris rapae and Tenebrio molitor, under laboratory conditions. This potentially makes these species viable biological control agents (Ye et al. 2010). Furthermore, Oscheius microvilli was recorded in Chongming Island, China, and showed a high level of effectiveness (Zhou et al. 2017).

Several studies have been carried out in the Middle East, but there is no available data about the diversity and activity of EPNs from Iraq. Therefore, the aims of this study were to survey, isolate, and identify indigenous EPNs that present in the Iraqi habitats.

\section{Materials and methods}

\section{Soil sampling and isolation of entomopathogenic} nematodes

Soil samples were collected from different sites of grassland, citrus, and date palms in three provinces of Baghdad, Iraq. Sub-samples were taken from a depth of up to 20 $\mathrm{cm}$, using a hand spade, from underneath the canopy of the trees. The insect-baiting technique of (Bedding and Akhurst 1975), using the last instar larvae of the greater wax moth, Galleria mellonella L., was used. The soil samples were transferred into plastic containers $(300 \mathrm{ml})$ with lids. A 7-10 last instar larvae were used for each container, 7 to 10 replicates were used for each soil sample. Then, these containers with the larvae were placed under lab conditions for 5-7 days. To encourage movement of potential nematodes in the soil, every day the containers were shacked and appropriate amount of sterilized water were added to avoid drying of the soil. The containers were checked every 3-4 days to remove infected larvae with EPNs. The infected larvae, based on color and shape, were transferred to the white trap individually (White 1927). Infective juveniles (IJs) emerged from the cadavers after 8-10 days (Kaya and Stock 1997). To sum up, the emerged IJs were maintained and stored inside a falcon tube $(15 \mathrm{ml})$ that had sterilized pieces of sponges at $8-10{ }^{\circ} \mathrm{C}$. To confirm the pathogenicity of collected nematodes, again last instar larvae of G. mellonella were inoculated by 100 emerged IJs/larva to observe same previous symptoms (Koch's postulates) (Kaya and Stock 1997).

\section{Molecular characterization and phylogeny} DNA extraction

The nematodes' DNA, as a single adult, was extracted using 5\% Chelex 100 solution (SIGMA, Bio-Rad Laboratories, Inc., USA) along with a tissue DNA extraction kit (Parstous Biotechnology, Mashhad, Iran). Individual nematodes were collected and transferred into a 1.5-ml micro-centrifuge tube. The sample was crushed, using a micro-pestle and subsequently $20 \mu \mathrm{l}$ of Chelex and $1 \mu \mathrm{l}$ of Proteinase K (Parstous, Iran) (www.parstous. com) were added. The tubes were then incubated at $64{ }^{\circ} \mathrm{C}$ for $3 \mathrm{~h}$, followed by $10 \mathrm{~min}$ at $95^{\circ} \mathrm{C}$ onto a hotplate (thermo-block) for heating; then they were centrifuged at $13,000 \mathrm{rpm}$ for $3 \mathrm{~min}$. Finally, the supernatants were transferred to a $0.1-\mathrm{ml}$ micro-tube and stored at $-20^{\circ} \mathrm{C}$ for use in the next step. In addition to this method, the Tissue DNA extraction kit was used for extraction of the DNA by following the procedure and protocol given by the manufacturer.

\section{Amplification of ITS and 185 genes}

For internal transcribed spacer (ITS) region amplification, the primer set of TW81 and AB28 (Joyce et al. 1994) was used. The PCR solution had a final volume of $25 \mu \mathrm{l}$ comprising of $6.25 \mu \mathrm{l}$ sterilized water, $12.5 \mu \mathrm{l} 2 \mathrm{X}$ Taq PreMix, $1 \mu \mathrm{l}$ of each primer, $1.25 \mu \mathrm{l}$ dimethyl sulfoxide, and $3 \mu \mathrm{l}$ genomic DNA. The PCR reactions were conducted in a thermo-cycle (A300 Fast Thermal Cycler, Hangzhou Longgene Scientific Instruments Co., Ltd. China). The PCR run consisted of initial denaturation at $94^{\circ} \mathrm{C}$ for $4 \mathrm{~min}$, followed by 35 cycles of $94^{\circ} \mathrm{C}$ for $1 \mathrm{~min}$, $55^{\circ} \mathrm{C}$ for $1 \mathrm{~min}$, and $72^{\circ} \mathrm{C}$ for $2 \mathrm{~min}$; and a final extension at $72{ }^{\circ} \mathrm{C}$ for $10 \mathrm{~min}$. Finally, the PCR product was electrophoresed for $40 \mathrm{~min}$ on $1 \%$ agarose gels with $10 \mathrm{X}$ TBE buffer 5\% and green-viewer (SYBR) was added to stain the gel. Finally, $2.5 \mu \mathrm{l}$ of DNA ladder and $3 \mu \mathrm{l}$ of the PCR product were loaded into each well of the gel. The size of amplified products was identified by comparing to 100-bp molecular DNA ladder (Parstous, Iran).

\section{DNA sequencing and analysis}

The PCR products of both strains with replicates were sent to Macrogen Co. (Korea) for sequencing. Then, the quality of chromatograms was checked and created the consensus sequences by using a DNA Baser Assembler (DNA Sequence Assembler v4 (2013), HeracleBioSoft, www.DnaBaser.com). Then, the DNA sequence was blasted against the NCBI database.

\section{Phylogenetic analysis Molecular analysis of ITS}

The evolutionary analysis of the genus Heterorhabditis isolate included nucleotide sequences from 30 valid and verified DNA sequences along with our sequence carried 
out, using the MEGA 7 software program (Kumar et al. 2016). The evolutionary history was inferred by using a maximum likelihood method, based on the $\mathrm{K} 2+\mathrm{G}$ (Kimura 1980). For Heterorhabditis, DNA sequences of Caenorhabditis elegans was used as an outgroup taxon (accession number EU131007) (Spiridonov et al. 2004). Branch support was determined by bootstrap analysis with 1100 replicates (Nguyen and Hunt 2007). Also, this program was performed for phylogenetic analyses, using the neighbor-joining method (Saitou and Nei 1987) with 10,000 replications of bootstrap (Felsenstein 1985). Then, the nucleotide distance was calculated by Clustal W and Clustal X version 2 (Larkin et al. 2007).

\section{Molecular analysis of 185}

The $18 \mathrm{~S}$ region was amplified, using $26 \mathrm{R}$ and $28 \mathrm{~A}$ primers (Nguyen and Hunt 2007). The previous procedures were followed for electrophoresis, sequencing, and analysis the PCR products. For phylogenetic analysis of the Heterorhabditis isolate, 27 valid sequences of the $18 \mathrm{~S}$ gene from species of the Heterorhabditidae family were retrieved from GenBank (NCBI) and analyzed together with the sequences of the current study. Clustal $\mathrm{X}$ (ver. 2) was used to align the sequences. For calculation of nucleotide distance and phylogenetic analyses, the MEGA.7 program was used.

\section{Results and discussion}

The studied isolates were identified and characterized based on both ITS and 18S genes of the rDNA. Based on color and shape, the infected larvae were sorted. Then, the molecular diagnostic method was conducted for all isolated species from all soil samples. After analysis, the sequences date and DNA sequences were blasted against the NCBI database in GenBank, all isolated species were found belonged to Heterorhabditis or Oscheius.

\section{Analysis using ITS sequence for Heterorhabditis species} The length of the ITS gene for the IRQ isolate was 825 bp. The BLAST analysis on the basis of the ITS gene for this population attributes to $99 \%$ of similarities and $96 \%$ of query coverage with $H$. bacteriophora (EF469774). The multiple alignments of a $799 \mathrm{bps}$ segment of ITS gene for 30 taxa showed that 221 sites were conserved, 553 sites were variable, 239 sites were singleton and 309 sites were parsimony informative. The phylogenetic tree reconstructed based on ITS sequences, using neighbor-joining analysis showed that the IRQ.1 isolate forms a monophyletic group with other Heterorhabditis bacteriophora isolates (Fig. 1). The mean inter-specific distance of ITS sequences was $0.027 \%$ (range 0.00 0.403 ), which was calculated by the Tamura 3-parameter model. There was a $0.002 \%$ difference between the Iraqi isolates and Heterorhabditis bacteriophora (EF469774) (Table 1).

\section{Analysis of the $18 \mathrm{~S}$ sequence of Heterorhabditis species} BLAST analysis, based on the $18 \mathrm{~S}$ gene for IRQ.1 isolate, showed that the similarity was $99 \%$ and the query coverage was $96 \%$ with $H$. bacteriophora (EF469774). The length of the $18 \mathrm{~S}$ gene for this isolate was $863 \mathrm{bp}$. In addition, the multiple alignments of a $737 \mathrm{bps}$ segment of $18 \mathrm{~S}$ region for 28 taxa, illustrated that 283 sites were conserved, 390 sites were variable, 314 sites were singleton and 75 sites were parsimony informative. The obtained results of the $18 \mathrm{~S}$ regions were similar to those that resulted from the ITS gene. In the phylogenetic analysis, IRQ.1 isolate of $H$. bacteriophora was placed in the same clade with isolates of Heterorhabditis. This was supported with a $100 \%$ bootstrap support value (Fig. 2).

The mean inter-specific distance among $H$. bacteriophora IRQ.1 isolate and other isolates of $H$. bacteriophora were $0.095 \%$ (range $0.00-0.97 \%$ ), which were calculated from the $18 \mathrm{~S}$ gene using the Tamura 3-parameter model. The nucleotide distance between the Iraqi population of H. bacteriophora and H. bacteriophora (EF469774) was 0.002\% (Table 2).

\section{Analysis of ITS region for Oscheius species}

The length of the ITS gene for IRQ.2 isolate was $855 \mathrm{bp}$. Then BLAST analysis of the ITS gene for the Iraqi population attributes to $98 \%$ similarities and $95 \%$ of query coverage with the ITS sequences of Oscheius myriophilus (MG551691). The phylogenetic tree based on ITS showed that O. myriophilus IRQ.2 forms a monophyletic group with other O. myriophilus isolates, and this group of Oscheius was placed in a single clade with other isolates of O. myriophilus (Fig. 3). Mean inter-specific distance of the ITS sequences was $0.59 \%$ (range 0.00-1.06). There was a $0.161 \%$ difference between the Iraqi isolate and O. myriophilus (KP792651).

\section{Analysis of 185 region for Oscheius species}

The length of the $18 \mathrm{~S}$ gene for IRQ isolate was 911 bps and the BLAST analysis based on this gene attributes to $98 \%$ similarities and $95 \%$ of query coverage that identity with the $18 \mathrm{~S}$ sequences of O. myriophilus (MG551691.1). For reconstructing the 18S tree, the multiple alignments of a 709 bps segment of $18 \mathrm{~S}$ gene for 32 taxa and an outgroup taxon (Steinernema carpocapsae, accession number: KJ950291) were used. The result showed that 378 sites were conserved, 321 sites were variable, 48 sites were singleton, and 273 sites were parsimony informative. The phylogenetic tree reconstructed based on $18 \mathrm{~S}$ sequences, using neighbor-joining analysis showed Oscheius IRQ.2 forms a monophyletic group with other isolates of $O$. 


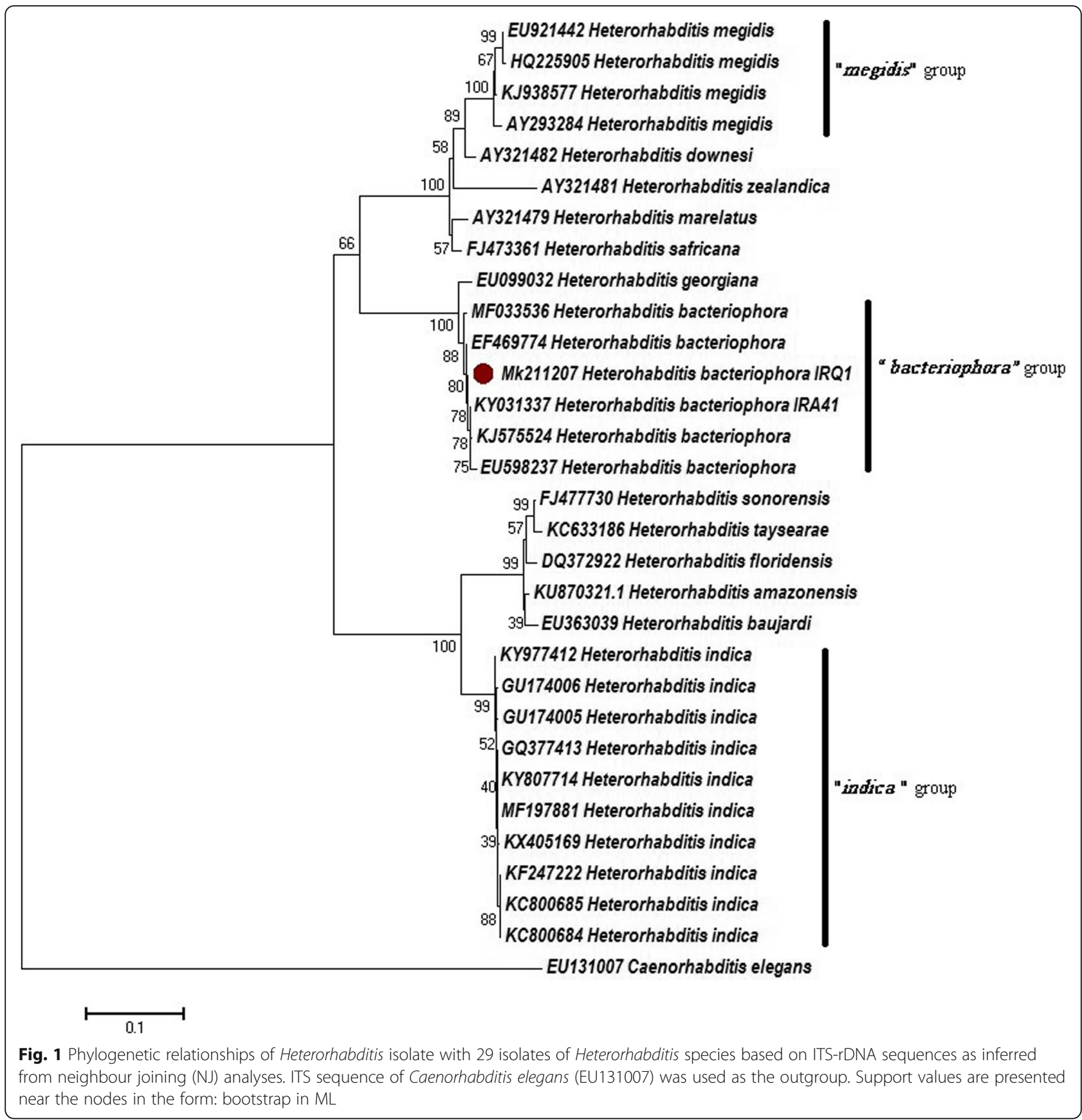

myriophilus. Figure 4 shows that the bootstrap value of support for the corresponding clade countering Oscheius IRQ.2 and other isolates was 99\%. Mean inter-specific distance of the $18 \mathrm{~S}$ sequences was $0.151 \%$ (range $0.00-0.27$ ), which was calculated by the Tamura 3-parameter model. There was a $0.005 \%$ difference between the Iraqi isolate and $O$. myriophilus (MG551691).

Distribution of EPN species and isolates in different areas could exhibit a significance in behavioral and physiological adaptation. Therefore, it is crucial for the successful use of EPNs, as biological control agents, to identify and document the locally adapted species or isolates of a particular region (Stock et al. 1999). Therefore, it is important to find an accurate identification method to understand the geographical distribution, behavior, and biodiversity of the Heterorhabditis species (Hominick 2002).

Recovery of the species of the Heterorhabditis and Oscheius genus from Baghdad suggests a higher species 
Table 1 Pairwise comparison on the number of nucleotide differences among some of Heterorhabditis species and isolates with Heterorhabditis bacteriophora isolate IRQ.1 based on ITS rDNA sequences

\begin{tabular}{|c|c|c|c|c|c|c|c|c|}
\hline & Heterorhabditis species & 1 & 2 & 3 & 4 & 5 & 6 & 7 \\
\hline 1 & MK21446 Heterorhabditis bacteriophora IRQ1 & & & & & & & \\
\hline 2 & KY031337 Heterorhabditis bacteriophora & 0.002 & & & & & & \\
\hline 3 & EF469774 Heterorhabditis bacteriophora & 0.002 & 0.003 & & & & & \\
\hline 4 & KJ575524 Heterorhabditis bacteriophora & 0.003 & 0.002 & 0.005 & & & & \\
\hline 5 & MF033536 Heterorhabditis bacteriophora & 0.006 & 0.008 & 0.005 & 0.009 & & & \\
\hline 6 & EU598237 Heterorhabditis bacteriophora & 0.006 & 0.005 & 0.008 & 0.006 & 0.012 & & \\
\hline 7 & MF197881 Heterorhabditis indica & 0.309 & 0.311 & 0.306 & 0.314 & 0.309 & 0.319 & \\
\hline 8 & KY977412 Heterorhabditis indica & 0.311 & 0.314 & 0.309 & 0.316 & 0.307 & 0.321 & 0.002 \\
\hline
\end{tabular}

diversity in Iraq and that needs further research and extensive sampling. The potential of some tentative endemic entomopathogenic forms in controlling endemic agricultural pests is another issue and could be tested, using endemic entomopathogenic strains. In the present study, the species $O$. myriophilus was characterized by its molecular data; however, it was successfully characterized by molecular sequences of two genomic fragments (ITS and 18S genies). The usefulness of molecular data to distinguish these species from its closely related forms has already been documented (Campos-Herrera et al. 2015).

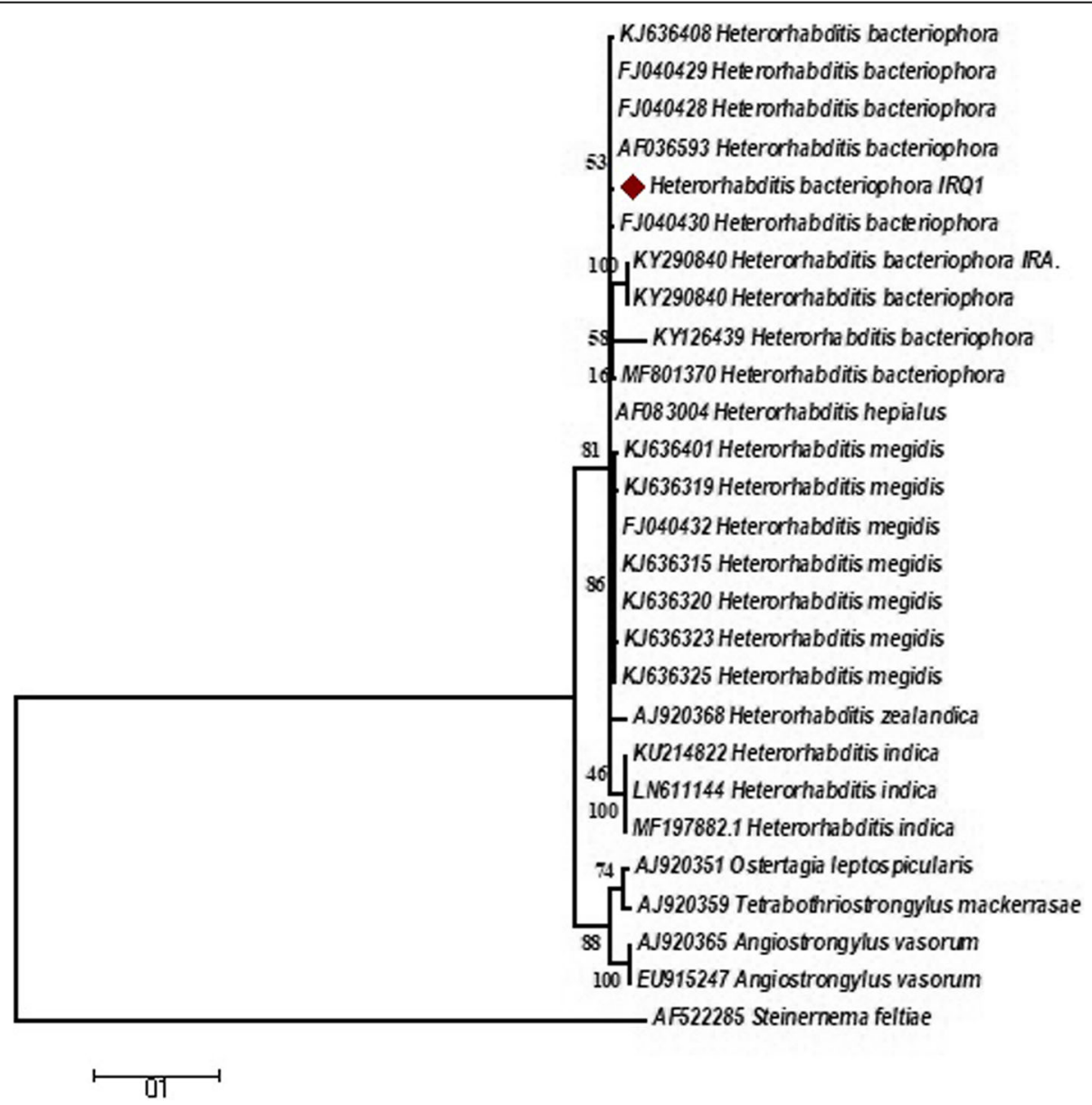

Fig. 2 Phylogenetic relationships of Heterorhabditis isolate with 26 isolates of Heterorhabditis species based on 185 sequences as inferred from maximum likelihood (ML) analyses. $18 \mathrm{~S}$ sequence of Steinernema feltiae (AF522285) was used as the outgroup. Support values are presented near the nodes in the form: bootstrap in ML 
Table 2 Pairwise comparison on the number of nucleotide differences among some of Heterorhabditis species and isolates with Heterorhabditis bacteriophora isolate IRQ.1 based on $18 \mathrm{~S}$ sequences

\begin{tabular}{|c|c|c|c|c|c|c|c|c|c|c|}
\hline & Heterorhabditis species & 1 & 2 & 3 & 4 & 5 & 6 & 7 & 8 & 9 \\
\hline 1 & Heterorhabditis bacteriophora IRQ.1 & & & & & & & & & \\
\hline 2 & KY290840 Heterorhabditis bacteriophora & 0.014 & & & & & & & & \\
\hline 3 & AF036593 Heterorhabditis bacteriophora & 0.002 & 0.012 & & & & & & & \\
\hline 4 & KJ636408 Heterorhabditis bacteriophora & 0.003 & 0.014 & 0.002 & & & & & & \\
\hline 5 & KY126439 Heterorhabditis bacteriophora & 0.029 & 0.034 & 0.028 & 0.029 & & & & & \\
\hline 6 & KY290840 Heterorhabditis bacteriophora & 0.014 & 0.000 & 0.012 & 0.014 & 0.034 & & & & \\
\hline 7 & MF801370 Heterorhabditis bacteriophora & 0.005 & 0.014 & 0.003 & 0.005 & 0.028 & 0.014 & & & \\
\hline 8 & AF083004 Heterorhabditis hepialus & 0.003 & 0.014 & 0.002 & 0.003 & 0.029 & 0.014 & 0.005 & & \\
\hline 9 & KJ636315 Heterorhabditis megidis & 0.008 & 0.019 & 0.006 & 0.008 & 0.034 & 0.019 & 0.009 & 0.005 & \\
\hline 10 & KU214822 Heterorhabditis indica & 0.017 & 0.028 & 0.015 & 0.017 & 0.044 & 0.028 & 0.019 & 0.014 & 0.961 \\
\hline
\end{tabular}

Obviously, phylogenetic analysis of the 18S rDNA and ITS rDNA sequence data to infer the relationships of Oscheius with other rhabditids, it was found that $H$. chongmingensis was in a monophyletic clade with $100 \%$ support together with $O$. colombianus, O. insectivorus, and O. myriophilus (Zhang et al. 2008).
H. bacteriophora is one of the most widely distributed EPNs in the world. (Adams et al. 2006; Hominick et al. 1996). This species was the most common and widely distributed EPNs in the north-west of Iran, followed by S. feltiae (Kary et al. 2009). The same species was isolated from neighboring countries such

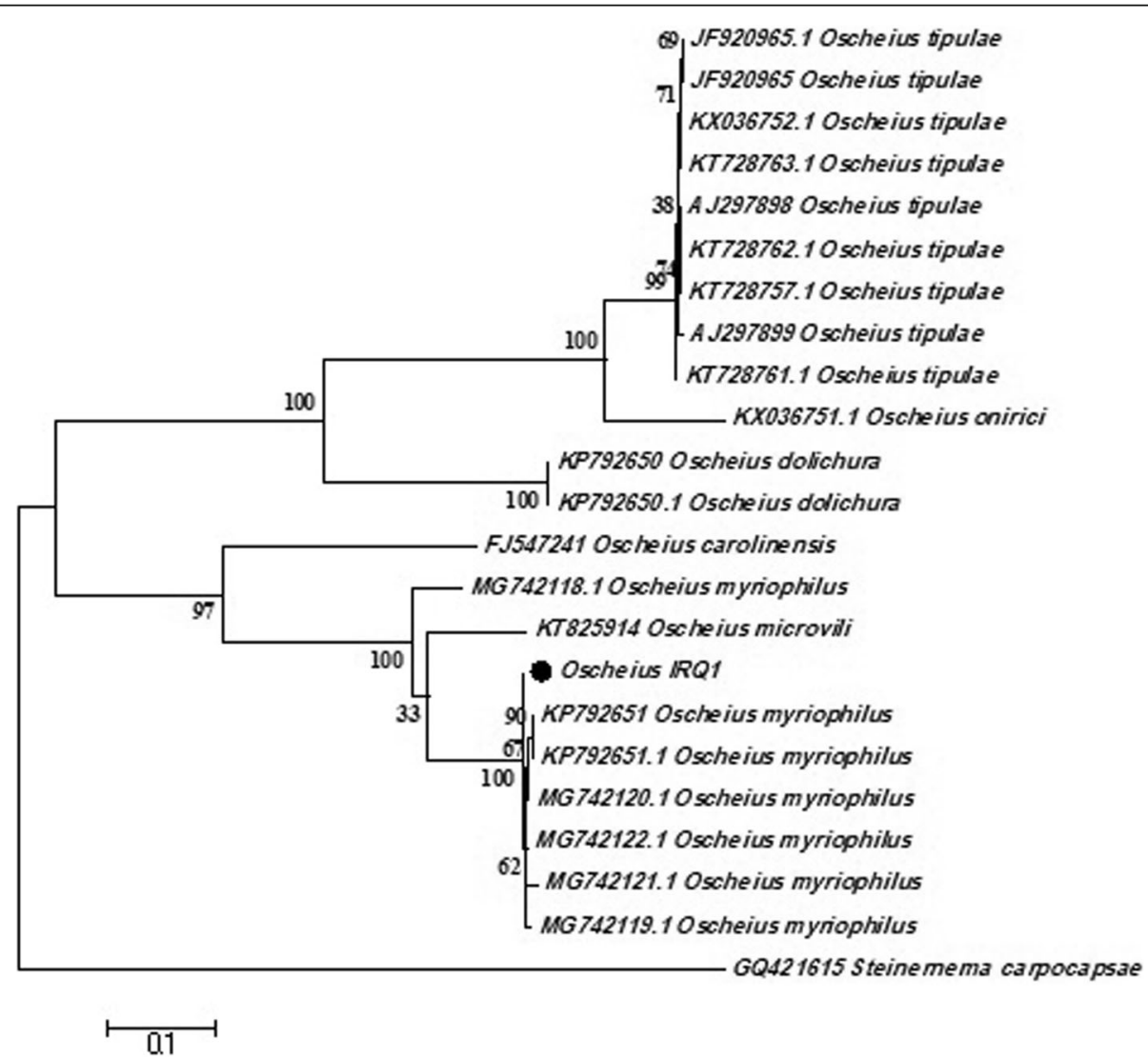

Fig. 3 Phylogenetic relationships of Oscheius isolate with 28 taxa based on ITS-rDNA sequences as inferred from maximum likelihood (ML) analyses. Steinernema carpocapsae (GQ421615) was used as the outgroup. Support values are presented near the nodes in the form: bootstrap in $\mathrm{ML}$ 


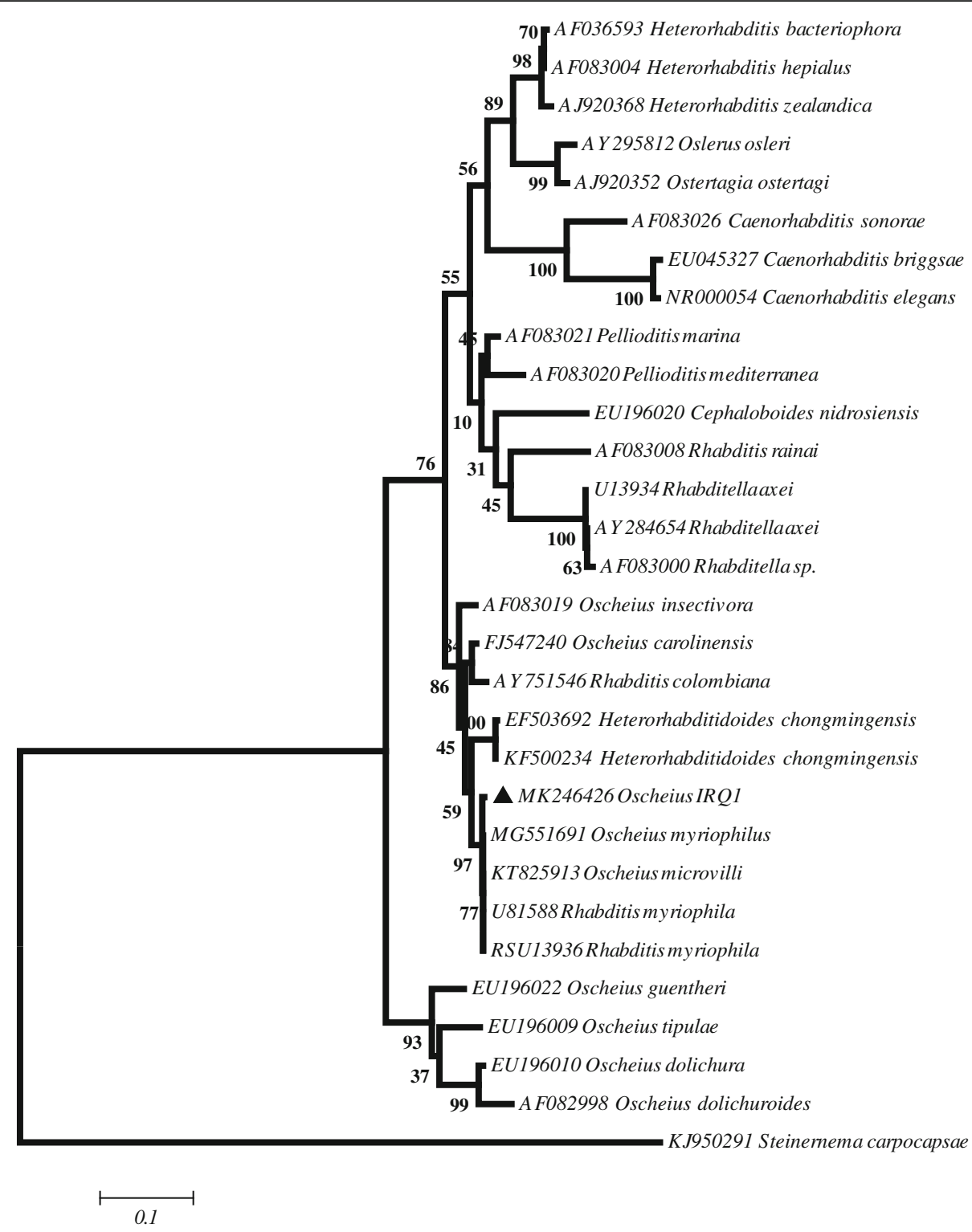

Fig. 4 Phylogenetic relationships of Oscheius isolates with 32 taxa based on 185 sequences as inferred from maximum likelihood (ML) analyses. Steinernema carpocapsae (accession number: KJ950291) was used as the outgroup. Support values are presented near the nodes in the form: bootstrap in ML

as Iran and the Mediterranean region (Karimi and Salari 2015). Heterorhabditis appears to be the dominant EPN genus in the Middle Eastern countries (Glazer et al. 1991; Iraki et al. 2000; Salama and Abd-Elgawad 2001).

Molecular characterization of nematodes is typically based on sequence data from the internal ITS gene (Reid et al. 1997). Molecular analysis was performed on females because their large size provided an appropriate amount of DNA. Sequencing of the nucleotides of organisms enables the use of the sequence differences among EPN isolates for identification and affirmation of new species (Szalanski et al. 2000; Spiridonov et al. 2004). The applications of nucleotide sequence data together with evolutionary species concepts are very supportive in the discovery and unfolding of new species (Spiridonov et al. 2004).

In the present study, the phylogenetic analysis based on the ITS gene showed a close relationship between $H$. bacteriophora and $H$. georgiana, which is similar to the results of Nguyen et al. (2008). Furthermore, in one clade, there is one isolate of $H$. georgiana placed within the isolates of $H$. bacteriophora (Malan et al. 2014; Karimi and Salari 2015). 


\section{Conclusion}

This is the first documented record of two species of nematodes isolated from the middle part of Iraq, and these are Heterorhabditis bacteriophora and Oscheius myriophilus. The presence of $H$. bacteriophora isolate in a dry hot habitat like the middle of Iraq is a significant contribution to the biogeography of these species, and this may lead to use EPNs in the biological control of insect pests of tropical regions.

\section{Acknowledgements}

The authors appreciate from research deputy of Ferdowsi University of Mashhad.

\section{Funding}

The work is part of the first author's PhD dissertation which was submitted to FUM and supported by a grant to JK(p.3/45368) provided by research deputy of FUM.

\section{Availability of data and materials}

All data are available in the GenBank.

\section{Authors' contributions}

JK and JBZ designed the work. JBZ collected the samples and did the experiments. JBZ and JK analyzed the data. JBZ, JK, and EMM were involved in the MS preparation and revised the paper. All authors read and approved the final manuscript.

\section{Authors' information}

JBZ is a researcher from Ministry of Higher Education and Scientific Research which conduct his PhD in FUM. JK is faculty of FUM, which involves teaching and researching of insect pathology. EMM is nematologist at FUM.

\section{Ethics approval and consent to participate}

NA

\section{Consent for publication}

This is to state that I give permission for the publication.

\section{Competing interests}

The authors declare that they have no competing interests.

\section{Publisher's Note}

Springer Nature remains neutral with regard to jurisdictional claims in published maps and institutional affiliations.

\section{Author details}

'Biocontrol Insect Pathology Lab., Department of Plant Protection, Ferdowsi University of Mashhad, Mashhad, Iran. ${ }^{2}$ Department of Plant Protection, Ferdowsi University of Mashhad, Mashhad, Iran.

Received: 23 January 2019 Accepted: 26 April 2019

Published online: 12 June 2019

\section{References}

Adams BJ, Fodor A, Koppenhöfer HS, Stackebrandt E, Stock SP, Klein MG (2006) Biodiversity and systematics of nematode-bacterium entomopathogens. Biol. Control 38(1):32-49

Akhurst R, Smith K (2002) 15 regulation and safety. In: Gaugler R (ed) Entomopathogenic nematology, vol 1. CABI, New York, pp 311-332

Bedding R, Akhurst R (1975) A simple technique for the detection of insect paristic rhabditid nematodes in soil. Nematologica 21(1):109-110

Boemare N (2002) Biology, taxonomy and systematics of Photorhabdus and Xenorhabdus. In: Gaugler R (ed) Entomopathogenic nematology, vol 1. CABI, New York, pp 35-56

Campos-Herrera R, Jaffuel G, Chiriboga X, Blanco-Pérez R, Fesselet M, Půža V et al (2015) Traditional and molecular detection methods reveal intense interguild competition and other multitrophic interactions associated with native entomopathogenic nematodes in Swiss tillage soils. Plant Soil 389(1-2):237-255

Darsouei R, Karimi J, Shokoohi E (2014) Oscheius rugaoensis and Pristionchus maupasi, two new records of entomophilic nematodes from Iran. Russ. J. Nematol. 22(2):141-155

Dillman AR, Chaston JM, Adams BJ, Ciche TA, Goodrich-Blair H, Stock SP, Sternberg PW (2012) An entomopathogenic nematode by any other name. PLoS Pathog. 8(3):e1002527

Felsenstein J (1985) Confidence limits on phylogenies: an approach using the bootstrap. Evolution 39(4):783-791

Glazer I, Gaugler R, Segal D (1991) Genetics of the nematode Heterorhabditis bacteriophora strain HP88: the diversity of beneficial traits. J. Nematol. 23(3):324

Hazir S, Kaya HK, Stock SP, Keskin N (2004) Entomopathogenic nematodes (Steinernematidae and Heterorhabditidae) for biological control of soil pests. Turk. J. Biol. 27(4):181-202

Hominick WM (2002) Biogeography. In: Gaugler R (ed) Entomopathogenic nematology, vol 1. CABI, New York, pp 115-143

Hominick WM, Reid AP, Bohan DA, Briscoe BR (1996) Entomopathogenic nematodes: biodiversity, geographical distribution and the convention on biological diversity. Biocontrol Sci. Tech. 6(3):317-332

Iraki N, Salah N, Sansour M, Segal D, Glazer I, Johnigk SA, Ehlers RU (2000) Isolation and characterization of two entomopathogenic nematode strains, Heterorhabditis indica (Nematoda, Rhabditida), from the West Bank Palestinian territories. J. Appl. Entomol. 124(9-10):375-380

Joyce, S., Reid, A., Driver, F., \& Curran, J. (1994). Application of polymerase chain reaction $(P C R)$ methods to identification of entomopathogenic nematodes. Paper presented at the Cost

Karimi J, Salari E (2015) Entomopathogenic nematodes in Iran: Research and Applied Aspects. In: Campos-Herrera R (ed) Nematode Pathogenesis of Insects and Other Pests. Springer International Publishing, Zurich, pp 451-476

Kary NE, Niknam G, Griffin CT, Mohammadi SA, Moghaddam M (2009) A survey of entomopathogenic nematodes of the families Steinernematidae and Heterorhabditidae (Nematoda: Rhabditida) in the north-west of Iran. Nematology 11(1):107-116

Kaya HK, Aguillera M, Alumai A, Choo HY, De la Torre M, Fodor A et al (2006) Status of entomopathogenic nematodes and their symbiotic bacteria from selected countries or regions of the world. Biol. Control 38(1):134-155

Kaya HK, Gaugler R (1993) Entomopathogenic nematodes. Annu. Rev. Entomol. 38(1):181-206

Kaya HK, Stock SP (1997) Techniques in insect nematology. In: Lacey L. (Ed.), Manual of techniques in insect pathology. Academic Press, San Diego, pp. 281-324.

Kimura M (1980) A simple method for estimating evolutionary rates of base substitutions through comparative studies of nucleotide sequences. J. Mol. Evol. 16(2):111-120

Kumar S, Stecher G, Tamura K (2016) MEGA7: molecular evolutionary genetics analysis version 7.0 for bigger datasets. Mol. Biol. Evol. 33(7):1870-1874

Lacey L, Grzywacz D, Shapiro-Ilan D, Frutos R, Brownbridge M, Goettel M (2015) Insect pathogens as biological control agents: back to the future. J. Invertebr. Pathol. 132:1-41

Larkin MA, Blackshields G, Brown N, Chenna R, McGettigan PA, McWilliam H et al (2007) Clustal W and Clustal X version 2.0. Bio Informatics 23(21):2947-2948

Lephoto TE, Featherston J, Gray VM (2015) Draft whole-genome sequence of Serratia sp. strain TEL, associated with Oscheius sp. TEL-2014 (Nematoda: Rhabditidae) isolated from a grassland in South Africa. Genome Announc 3(4):e00747-e00715

Malan AP, Knoetze R, Tiedt L (2014) Heterorhabditis noenieputensis n. sp. (Rhabditida: Heterorhabditidae), a new entomopathogenic nematode from South Africa. J. Helminthol. 88(2):139-151

Nguyen K, Hunt D (2007) Entomopathogenic nematodes: systematics, phylogeny and bacterial symbionts, vol 7 Nematology Monographs \& Perspectives: Brill

Nguyen KB, Puza V, Mr acek Z (2008) Steinernema cholashanense n. sp. (Rhabditida, Steinernematidae) a new species of entomopathogenic nematode from the province of Sichuan, Chola Shan mountains, China. Invertebr Pathol 97:251-264

Reid AP, Hominick WM, Briscoe BR (1997) Molecular taxonomy and phylogeny of entomopathogenic nematode species (Rhabditida: Steinernematidae) by RFLP analysis of the ITS region of the ribosomal DNA repeat unit. Syst. Parasitol. 37(3):187-193

Saitou N Nei M (1987) The neighbor-joining method: a new method for reconstructing phylogenetic trees. Mol. Biol. Evol. 4(4):406-425 
Salama H, Abd-Elgawad MM (2001) Isolation of heterorhabditid nematodes from palm tree planted areas and their implications in the red palm weevil control. J. Pest. Sci. 74(2):43-45

Shapiro-llan D, Hazir S, Glazer I (2017) Basic and applied research: entomopathogenic nematodes. In: Lacey LA (ed) Microbial Control of Insect and Mite Pests. Elsevier, London, pp 91-105

Spiridonov SE, Reid AP, Podrucka K, Subbotin SA, Moens M (2004) Phylogenetic relationships within the genus Steinernema (Nematoda: Rhabditida) as inferred from analyses of sequences of the ITS1-5.8 S-ITS2 region of rDNA and morphological features. Nematology 6(4):547-566

Stock SP, Pryor BM, Kaya HK (1999) Distribution of entomopathogenic nematodes (Steinernematidae and Heterorhabditidae) in natural habitats in California, USA. Biodivers. Conserv. 8(4):535-549

Szalanski AL, Taylor DB, Mullin PG (2000) Assessing nuclear and mitochondrial DNA sequence variation within Steinernema (Rhabditida: Steinernematidae). J. Nematol. 32(2):229

Thomas GM, Poinar GO Jr (1983) Amended description of the genus Xenorhabdus Thomas and Poinar. Int. J. Syst. Evol. Microbiol. 33(4):878-879

Torres-Barragan A, Suazo A, Buhler WG, Cardoza YJ (2011) Studies on the entomopathogenicity and bacterial associates of the nematode Oscheius carolinensis. Biol. Control 59(2):123-129

Torrini G, Mazza G, Carletti B, Benvenuti C, Roversi PF, Fanelli E et al (2015) Oscheius onirici sp. n.(Nematoda: Rhabditidae): a new entomopathogenic nematode from an Italian cave. Zootaxa 3937(3):533-548

White $G$ (1927) A method for obtaining invective nematode larvae from culture. Science (Washington) 66:302-303

Ye W, Torres-Barragan A, Cardoza YJ (2010) Oscheius carolinensis n. sp.(Nematoda: Rhabditidae), a potential entomopathogenic nematode from vermicompost. Nematology 12(1):121-135

Zhang C, Liu J, Xu M, Sun J, Yang S, An X, Gao G, Lin M, Lai R, He Z, Wu Y, Zhang K (2008). Heterorhabditidoides chongmingensis gen. nov., sp. nov. (Rhabditida: Rhabditidae), a novel member of the entomopathogenic nematodes. J Invertebr Pathol 98(2):153-168

Zhou G, Yang H, Wang F, Bao H, Wang G, Hou X et al (2017) Oscheius microvilli $\mathrm{n}$. sp.(Nematoda: Rhabditidae): a facultatively pathogenic nematode from Chongming Island, China. J. Nematol. 49(1):33

\section{Submit your manuscript to a SpringerOpen ${ }^{\circ}$ journal and benefit from:}

- Convenient online submission

- Rigorous peer review

- Open access: articles freely available online

- High visibility within the field

- Retaining the copyright to your article

Submit your next manuscript at $\boldsymbol{\nabla}$ springeropen.com 